\title{
An Analysis of John Steinbeck's Humanistic Concern in Of Mice and Men
}

\author{
Fanbin Meng ${ }^{1} \&$ Fengjuan Liu $^{2}$ \\ ${ }^{1}$ School of Foreign Languages, Inner Mongolia University for the Nationalities, China \\ ${ }^{2}$ English College, Dalian University, China \\ Correspondence: Fanbin Meng, School of Foreign Languages, Inner Mongolia University for the Nationalities, \\ Tongliao City, Inner Mongolia, China.
}

\author{
Received: May 21, 2018 Accepted: June 17, 2018 Online Published: August 22, 2018 \\ doi:10.5539/ells.v8n3p39 URL: https://doi.org/10.5539/ells.v8n3p39
}

\begin{abstract}
Mostly read and admired as a Depression writer, John Steinbeck enjoyed a high prestige in the world for his grand theme of humanity and ingenious craftsmanship. Different from other Depression writers, Steinbeck succeeds in making people keep a refreshing faith in humanity through devastation and desolation. This paper aims at analyzing Steinbeck's humanistic concern in Of Mice and Men, through two main aspects, the desire for land and the hunger for intimacy. In the conclusion part, it is pointed out that beyond the gloom and despair, the dream for the paradise future and the quest for genuine human relations is always the noble ideal to seek; equality, benevolence and fraternity is forever the sublime Christian spirit calling people to return, though they're lost in their direction for the time being, to their holy native land.
\end{abstract}

Keywords: depression, isolation, land, intimacy, humanistic concern

\section{Introduction}

John Steinbeck (1902-1968) was a significant social realist writer in the 1930s America. Of Mice and Men, one of his three powerful novels of the late 1930s focusing on the California laboring class, became a best seller when it appeared in 1937, the other two being In Dubious Battle (1936) and The Grapes of Wrath (1939). All the three were set on the scene of the Great Depression period, in the wake of the Wall Street Crash of 1929 (Ditsky, 2000 , p. 28). The mood of the 1930 s exactly took after the literary connotation of the economic crisis: depression. In the $1930 \mathrm{~s}$, many western countries had stepped onto the stage of modern industrialization. Urbanization and secularization had begun to subvert the mainstream traditional values, religion was no longer the center of human beliefs, especially with the impact of Darwinism, and the world became a black void where no standard of justice and morality was observed. Humanity was alienated by the intervention of cold machines, the plight of mere existence and the barrenness of spiritual support. The sense of estrangement dominated (Loftis, 1990, p. 46). In the Great Depression, subjected to the capricious plundering and exploitation of industrial capitalists and their agents banks, tenants, who lost their land and home had to leave their native places and became migrant workers, living from hand to mouth, engaged in temporary jobs, shifting from one ranch to another. In the bleak years of the thirties, life became a nightmarish experience of poverty and brutal struggle for survival. All they yearned for was a piece of land that belonged to them, where they could plant some crops and vegetables, raised poultry and livestock to sustain their life, and where they could build a house to keep themselves warm in winter. Of Mice and Men was set just in such background.

\section{The Desire for Land}

The title of the novel is cited from one stanza of To a Mouse by Robert Burns (1759---1796):

But, Mousie, thou art no thy lane

In proving foresight mays vain:

The best laid schemes O'mice an'men

Gang aft a-gley,

An' lea'e us nought but grief an'pain, 
For promised joy (Wu, 2007, p. 297)

Such lines are the vivid portrayal of the human existence of the 1930s, full of tragic implication and philosophical insight (Timmerman, 1986, p. 80). In the poem, the house of a sleek timid mouse was ruined by a plough by chance. Though the mouse endeavored to store up food and nibbled in leaves and stubbles to make a cozy house to spend a weary winter beneath the blast, the cruel cutter-blade subverted his house and crashed his plan. In the bleak December winds, there was no green moss to be found to build a new house. Homeless and panic, the fate of the mouse seemed doomed. Then the poet sighs that though it is considered to be wise to lay up against a rainy day, the best schemes of mice and men often go awry. In the poem, the cutter-blade, cold, made of metal, symbolizes the force of caducity. The mouse, a lower mammal, is forced to be on the road again and again after his house is destroyed, living a turbulent life in panic. He is at the mercy of some force invisible and overwhelming. In reality, modern industrialization deprived people of their land they became landless and had to look for temporary employment to live on; but agricultural machinery made laborers cheap and therefore restlessness and insecurity characterized their life tracks. In the face of this monster-like faceless enormous economic machine, sympathy, passion, love, faith, hope, and all those unrelated to physical materialization seemed to be devastated at a threatening speed. So the mice and men had the same fate. What they wanted in the world was not much: for the mice, a small cozy house, for the men, a piece of land belonging to themselves. But what awaited both was disaster and despair.

So the doomed tragedy of the main characters is hinted already in the title.

As for the desire for the possession of a piece of land, it is the driving power of the life of George and Lennie in the depressing surroundings. Such an ambition kindled their hope for the future, and witnessed their journeys, companionship, the unavoidable death and sheer despair. The name of George Milton is in fact imbued with profound message. George, as a name, originates from Greek, the meaning of which is land, which echoes the cry for land of George the person in the novel. John Milton, the greatest English poet after Shakespeare, composed two magnificent long poems Paradise Lost (1665) and Paradise Regained (1667). Steinbeck's arrangement for George's family name of course is not at random. For George, a piece of land of his own is like a paradise always in his mind. It doesn't have to be large, just enough for him and Lennie to sustain their life. It is a paradise in his vision to work for and live by, and a paradise to establish his identity as a decent human. The quest for such a paradise is the inspiration of the life of both his and Lennie's. For Steinbeck, the appeal for the restoration to an idyllic life is penetrated fully enough just through the name of George Milton.

But what quenches George's flames for a better life and agonizes the reader's heart is that in the end the paradise proved to be a mirage. It remained only in the eyes of Lennie when he looked off across the pool and up the darkening slopes of the Gabilans. It was the last image in Lennie's mind when he blew his last breath. A shot took his life but framed the picture of the paradise in the eyes of an innocent soul. So what is the implied purpose of Steinbeck by the coining of the name of George Milton and the related dream for the paradise of land? It seems ambiguous. The hope for the paradise dies in the heart of George, the wretched and tortured living, but lives in the mind of Lennie, the innocent and sanguine dead. A faith in humanity seems to transcend the gloom and despair, which makes Steinbeck apart from other Depression writers of the 1930s (Chang, 1995, p. 355).

\section{The Hunger for Intimacy}

Loneliness and alienation set the tone for the whole novel and the hunger for intimacy seems like an ache that bites everybody's heart. The relationship between George and Lennie, the swamper Candy and his old dog, the stable buck Crooks' protective isolation, the tragic fate of Curley's wife - all these converge at such a basic human need, which fails to be met with, no matter how hard the efforts are made.

Much is said by George in the first chapter on the night before he and Lennie reached the ranch that they were expected to work on. "Guys like us, that work on ranches, are the loneliest guys in the world. They got no family. They don't belong no place. They come to a ranch an' work up a stake and then they go inta town and blow their stake, and the first thing you know they're poundin' their tail on some other ranch. They ain't got nothing to look ahead to." (Of Mice and Men, 1993, pp. 13-14) So in this insecure lonely world, with the doomed fate looming ahead, companionship and intimacy is so dearly hankered for but yet so rarely obtained.

George, to compare to his partner Lennie, was a short smart and practical guy, with restless eyes, and with sharp strong features. On the contrary, Lennie was huge, shapeless of face, with large pale eyes, with wide sloping shoulders, and walked heavily in the way of a bear dragging his paws. They were a queer match, but they enjoyed each other's companion and were inseparable. Seemingly, Lennie, who was retarded, kept forgetting things and making trouble though indeliberately and innocently, was a burden to George, just as George complained that he could live an easy and nice life if he didn't have Lennie on his tail and might even have a girl. 
But why George still kept Lennie beside him instead of abandoning him? He needed Lennie in his life and this need was emotional. Though Lennie always got themselves cornered and they had to run away from one ranch to another making good their escape, he was not a trouble-maker in George's eyes; though for most of the time Lennie did not exactly understand what George was talking about and Gorege's speech turned to be a monologue of his own, he was a loyal listener in George's eyes. In Lennie's world, George was God and the one that guided his life. In the indifferent unreliable world, George was an insignificant man of no identity, but within the world of him and Lennie, he was a man of value and authority being worshipped, giving orders and making decisions. In Lennie, he saw his meaning of existence. So Lennie endowed his life with dignity and worth. Moreover, Lennie was harmless and innocent and was so loyal to him, and he was the only man in the world that George could trust with full conviction. And accordingly, Lennie was the only man that George could give his heart to without reservation.

Lennie and George were both born in Auburn. They used to play together in childhood and when Lennie's aunt Clara, who raised him up, died, he just came along with George out working. He was too dumb to take care of himself. He would do anything George told him to do without hesitation. At first, George took a lot of fun playing jokes on Lennie, which made him feeling pretty smart, for Lennie was too dumb even to know he had a joke played on him. George did not stop his nasty jokes until one day Lennie nearly drowned himself after he got the order from George to jump in though he could not swim, and was so grateful and nice to George for pulling him out of water forgetting that it was George who told him to jump in. He was a nice fellow, as George told others and as Slim observed.

Lennie was like a child, not knowing how to conduct himself. He imitated whatever George did and kept watching George to see whether he had it just right. He would look timid and spoke softly to George in the way of an anxious baby, especially when he realized he had made some trouble. What was peculiar about him, and what aroused the reader's curiosity was that he liked to pet something soft and slippery. His deed of keeping a dead mouse in his pocket at the first chapter might seem eccentric, horrible and nauseating. Then we came to know why Lennie and George had to quit their job on the former ranch in Weed, to be exact, it was not "quitting", but "fleeing". Lennie wanted to touch the red dress of a girl on the ranch. The girl was terrified by his strength and squawked, but Lennie held on because he was so scared and that was the only thing he could think to do. So George had to sock him over the head with a fence picket to make him let go. Then the girl sued Lennie at the court for raping her and the guys in Weed started a party out to lynch Lennie. So Lennie and George managed to scram out of there. Then as the story developed, we got to know that Lennie petted a pup to death and accidentally strangled Curley's wife while he was caressing her soft silky hair, which led to Lenne's own tragedy. Here Lennie's desire for touching or petting is a symbol. This outward visual "touching" or "petting" comes from the inward longing for intimacy, which is displayed further through the portrayal of some other characters, Candy, Crooks and Curley's wife as well.

The absence of intimacy and communication predominates the novel and characterizes the age of the production of the novel - the indifferent 1930s. But the death of the mouse, the pup, the woman (Curley's wife) and Lennie seems to tell that this basic human need could not be met with and what awaits this human wish is nothing but the doomed tragedy. So it is no wonder why people found it strange that Lennie and George were in company. "I never seen one guy take so much trouble for another guy" (Of Mice and Men, 1993, p. 22) The boss on the ranch such commented and even doubted that George meant to profit from Lennie. Slim also showed his interest in their travelling around together. "Ain't many guys travel around together... I don't know why. Maybe ever'body in the whole damn world is scared of each other" (Of Mice and Men, 1993, p. 35) And Slim thought it funny how George and Lennie strung along together. "Hardly none of the guys ever travel together. I hardly never seen two guys travel together. You know how the hands are, they just come in and get their bunk and work a month, and then they quit and go out alone. Never seem to give a damn about nobody." (Of Mice and Men, 1993, p. 39) In the Godless world, both George and Lennie saw benevolence, tolerance and fraternity in each other, and they were each other's God, a supporter and guide to sustain their life.

The old swamper Candy was the first man George and Lennie encountered on the ranch. He lost his hand right on the ranch and therefore was given a swamping job. With no friends and relatives, he had only his old dog for company. The description of the old dog is seen several times in the novel. His anility is captured so vividly in words that the reader cannot help regarding him as a symbol and taking his fate as a fable. The first time that the dog was introduced to the reader was that he was walking at the heels of Candy, dragfooted, gray of muzzle, and with pale, blind eyes. "The dog struggled lamely to the side of the room and lay down, grunting softly to himself and licking his grizzled, moth-eaten coat." (Of Mice and Men, 1993, p. 24) It is obvious to see that the dog was of no value and his days could be counted. But such an old fellow was an absolute nuisance in others' eyes, 
especially Carlson, who kept complaining that the dog stunk like hell and suggested to shoot the dog to put him out of misery. For in Carlson's opinion, the dog was no good either to Candy or to himself. That is equal to say, out of Steinbeck's intention, that when one is proved to be out of use, he has no right to be even allowed to exist in the world. Though Candy protested, saying that he had the dog since he was a pup, bragging with pride what an excellent sheep dog he used to be, nobody was on his side to stop the dog's "sentence to death". The dog was shot dead and thus Candy lost his company and his link of intimacy broke. What saddened him more was that through his dog he saw his own future, as he said to George and Lennie "They'll can me purty soon, jus'as soon as I can't swamp out no bunk houses they'll put me on the county... You seen what they done to my dog tonight? They says he wasn't no good to himself nor nobody else. When they can me here I wisht somebody'd shoot me." (Of Mice and Men, 1993, p. 60)

The dog's death reflects not only Old Candy's fate but all those migrant workers'. They were doomed. Everybody was alone and lived in his own isolated world. The intimate relationship of trust and loyalty between the man and the dog could not even stand.

The introduction to the negro stable buck Crooks occupies the major part of Chapter Four. He had lean face, lined with deep black wrinkles, and his lips were pain-tightened. His body was bent over to the left by his crooked spine. He had his bunk in the harness room, which was swept and fairly neat. He was a proud and aloof man, keeping his distance and demanding that other people keep theirs. The same as the other workers on the ranch, he had no real friends, but different from them, who had somewhat gone dumb to intimate communication and become nonchalant both to the inner emotional world and outward indifferent human relations, he was rather sensitive and delicate in heart. As a black man, he suffered twofold oppression, one being of class discrimination, the other of racial prejudice. Therefore his sense of loneliness was poignant and his agony doubled. His indignation and his cry for intimacy burst out like thunderstorm as he talked to Lennie, who came to his door for petting the puppy, though the other could hardly understand what he was driving at. He complained that he was not wanted in the bunk house and had no chance to play with the skinners for he was black and people said he stank. He whined “A guy needs somebody---to be near him. A guy goes nuts if he ain't got nobody. Don't make no difference who the guy is, long's he's with you... a guy gets too lonely an' he gets sick." (Of Mice and Men, 1993, pp. 72-73) Here, at the barn, an isolated island on the ranch, Lennie turned to be the only human that Crooks unlocked his heart to, though the irony was that Lennie was ignorant to his speech and was not the very person for a sound communication. He was talking to a person who could not give a response. But the point was that Lennie was a harmless listener. In the presence of Lennie, Crooks unloaded his guard, recalling his old good days, pouring out how vacant and forsaken life was without a friend. He envied Lennie for he had George, someone he confided in and someone he was always sure would come back, not like him, who spent time reading and thinking alone, getting nothing to measure by, having nobody to tell him if he was asleep...

Crooks, in the novel, is the mouthpiece of the author. Steinbeck's sympathy for the miserable lower class and condemnation for the merciless exploiting class is given full expression through the fruitless battle cry of the most insignificant soul Crooks. The hunger for intimacy echoed so vehemently in Crooks' lament and denouncement, but in vain.

The only female character in the novel, the victim of Lennie's uncontrollable desire for petting, the very cause for Lennie's fleeing from the ranch and indirect cause for his death, is Curley's wife. She was first known to the reader from Old Candy's gossip mouth, as a "tart". Under the observation of Candy, she gave slim the eye and she gave Carlson the other eye. She seemed to be a disgusting but interesting topic on the ranch, an inspiring and exciting object mentioned to the new comers. In the words of Whit, "She ain't concealin' nothing. I never seen nobody like her. She got the eye goin' all the time on everybody. I bet she even gives the stable buck the eye. I don't know what the hell she wants." (Of Mice and Men, 1993, p. 51) Such words were enough to say that she was a flirt. She made her first appearance when George and Lennie were alone in the bunk house their first day. She was rather erotic with full, rouged lips and heavily made-up wide-spaced eyes. She was decked out in such a gaudy style that one could think of her as nothing but a cheap shallow woman. And when she was addressing to the two men, she put her hands behind her back and leaned against the door frame so that her body was thrown forward. As she caught sight of Lennie's fascination with his eyes moving down over her body, she chose to look at her fingernails, smiling archly and twitching her body. Her seductive body movement convinced both the men and the reader that she was an immoral woman. The excuse she offered to be in the bunk house was that she was looking for her husband Curley and later on Curley was seen burst into the room excitedly demanding the whereabouts of his wife, as said sarcastically by Whit that Curley spent half his time looking for her, and the rest of the time she was looking for him. So immediately after the disappearance of Curley's wife, George realized 
that she was a time bomb, a malicious danger, and warned Lennie to keep away from her for he "never seen no piece of jail bait worse than her" (Of Mice and Men, 1993, p. 32) and she was a rattrap if he had ever seen one. So far, the impression of Curley's wife on the reader was that the purpose she was looking around all the time on the ranch was for dalliance, just like a bitch in the heat, a "tart" as sneered at.

Then in Chapter Four, on a Saturday night when all the guys went out for fun except the "weak ones", who met each other in Crooks' room, the reader came to realize what an extraordinary woman she was. She said amusedly to Crooks, Candy and Lennie, the three men who were scared of and avoided talking to her, "You're all scared of each other, that's what. Ever'one of you's scared the rest is goin' to get something on you." (Of Mice and Men, 1993, p. 77) She said what exactly Slim said previously in Chapter Two. Slim, a jerkline skinner, who conducted himself in a manner of royalty and majesty, was considered authority among the workers and his authority was great to the extent that his word was taken on any subject. Not only did he win admiration from the fellow workers, but also reverence from his employers. He was a man of decency. Moreover, he was a man of understanding and sympathy. "His ear heard more than was said to him, and his slow speech had overtones not of thought, but of understanding beyond thought." (Of Mice and Men, 1993, p. 34) He was the only man in the novel who lived in but saw through the world, the only man who possessed the tact to tackle life through kind of balance. So it is amazing that Curley's wife owned the same wisdom as Slim. She had such a sharp insight that she mocked at Candy's dream for their own land, calling it "baloney". She was smart enough to see everything, though malicious enough as well, and to see people's relations through. When Candy and Crooks asked her to keep away from the room by the threat of reporting to the boss, she took her advantage of the position as Curley's wife and pointed out the ruthless truth "Nobody'd listen to you an' you know it. Nobody'd listen to you", which reduced Crooks to nothing - no personality, no ego - nothing to arouse either like or dislike, which made Candy subside to admit the fact in a fable voice. She was correct, though cruel, to make everybody totally aware of his position of no identity. Confronted with the three men, pitiful and powerless, she was like a fearless roaring lioness. She vented her anger: Why everybody was out for fun on a Saturday night but she couldn't? Why she had to confine herself to her own room with a husband whom she hated? Why she had no liberty to talk to people? So far, the reader's impression on her is refreshed. She was, in fact, walking around the ranch for somebody to talk to, not for flirtation. She was a neglected woman suffering for want of communication. She was living in hunger for intimacy. Such a hunger of hers was revealed further in Chapter Five, when she came across Lennie. "Why can't I talk to you? I never get to talk to nobody. I get awful lonely." (Of Mice and Men, 1993 , p. 86) "I get lonely...You can talk to people, but I can't talk to nobody but Curley. Else he gets mad. How'd you like not to talk to anybody?" (Of Mice and Men, 1993, p. 87) "Wha's the matter with me? Ain't I got a right to talk to nobody? Whatta they think I am, anyways?" (Of Mice and Men, 1993, p. 87) "Seems like they ain't none of them cares how I gotta live." (Of Mice and Men, 1993, p. 88) Then, to Lennie, the man she considered nice and felt to be safe with, she told her own story, the same as the other lonely soul Crooks, who found confidence in Lennie as well. When she got to know that Lennie liked to pet nice soft things with his fingers, she invited him to stroke her hair. But Lennie couldn't help stroking harder and harder, which terrified her and she began to struggle and scream. Stirred in fear, Lennie closed her mouth and nose with his other hand. In the mess of struggling, her neck was broken and she died.

She was a woman of no identity, having no name but being called Curley's wife. Nobody understood her. But she was shrewd and pungent, and was audacious enough to cry for her right. Steinbeck's depiction of her dead body is profoundly impressive. "Curley's wife lay with a half-covering of yellow hay. And the meanness and the plannings and the discontent and the ache for attention were all gone from her face. She was very pretty and simple, and her face was sweet and young. Now her rouged cheeks and her reddened lips made her seem alive and sleeping very lightly. The curls, tiny little sausages, were spread on the hay behind her head, and her lips were parted." (Of Mice and Men, 1993, pp. 92-93) Here Steinbeck employs aesthetic elegiac tone to mourn and defend her. Curley's wife, a woman of no name, who got no sympathy from her fellows but was regarded and misunderstood as a "tart" (Agatha, 1975, p. 67), in fact was a real human longing for normal emotions, and in this regard, she was a warrior in her spirit. All the meanness, plannings, discontent and ache for attention were not the real her. The murderer of her life was not Lennie, but that brutal unfair society. The real her was pretty and simple, and she was sweat-natured. Her parted lips seemed to tell her tragic fate of injustice, her young dream for life, and to cry out her hunger for intimacy.

\section{Conclusion}

According to the above analysis, it is safe to conclude that $O f$ Mice and Men is a book of humanistic concern. The land, where humans get warmth and nourishment, and where they rear their posterity and develop their civilization, in literary metaphor, is mother's embrace. The loss of land symbolizes the breaking off of the link 
with mother. Therefore, humans lost not only their physical home, but also spiritual support and emotional comfort. The loss of the intimacy with the land and with emotional contact drove people restless and mentally sick. Nevertheless, through the death of the two innocent people, Lennie and Curley's wife, Steinbeck seems to emphasize that the dream for the paradise future and the quest for genuine human relations is always the noble ideal to seek. Equality, benevolence and fraternity is forever the sublime Christian spirit calling people to return, though they're lost in their direction for the time being, to their holy native land.

\section{References}

Agatha, T. (1975). John Steinbeck: On the Nature of Creative Process in the Early Years. Lincoln: University of Nebrasca.

Chang, Y. X. (1995). A Survey of American Literature. Tianjin: Nankai University Publishing House.

Ditsky, J. (2000). John Steinbeck and the Critics. New York: Camden House.

Loftis, A. (1990). The Short Novels of John Steinbeck: Critical Essays with a Checklist to Steinbeck Criticism. Ed. Jackson J. Benson. Durham: Duke University Press.

Steinbeck, J. (1993). Of Mice and Men. New York: Penguin Books.

Timmerman, J. H. (1986). John Steinbeck's Fiction: The Aesthetics of the Road Taken. Norman: University of Oklahoma Press.

Wu, W. R. (2007). History and Anthology of English Literature. Beijing: Foreign Language Teaching and Research Press.

\section{Copyrights}

Copyright for this article is retained by the author, with first publication rights granted to the journal.

This is an open-access article distributed under the terms and conditions of the Creative Commons Attribution license (http://creativecommons.org/licenses/by/4.0/). 